\title{
TEACHER-STUDENT CLOSENESS IN LEARNING ENGLISH AT SMK NADHLATUN NASYIIN KADUR PAMEKASAN
}

\author{
Mohammad Amiruddin ${ }^{1)}$, Chairul Fajar Tafrilyanto ${ }^{2)}$ \\ Universitas Madura ${ }^{12)}$ \\ Email: amiruddin@unira.ac.id \\ Email: fafan_math@unira.ac.id
}

\begin{abstract}
This study aims to find out (1) the ways of teacher to keep his closeness to the students at SMK Nadhlatun Nasyiin Kadur Pamekasan and (2) the role of teacherstudent closeness in learning English at SMK Nadhlatun Nasyiin Kadur Pamekasan. This study is a quantitative research by using descriptive case study approach. The participants of this study are students of grade VII at SMK Nadhlatun Nasyiin Kadur. Observation and interviews with teacher and students were conducted to get the data of teacher-student closeness. The results of the study show that the teacher have five ways to keep his closeness to his students those are saying "hello/assalamualikum or calling the students' name coming to the classroom, giving the students some question to have an interaction in English, giving some tasks, motivating students to speak English, and inviting students to talk in English. The roles of teacher-student closeness in learning English at SMK Nadhlatun Nasyiin Kadur Pamekasan are students have motivation to learn and to communicate in English dan they have low anxiety level in learning and talking in English.
\end{abstract}

\section{Keywords : Closeness, English Learning}

\begin{abstract}
Abstrak: Penelitian ini bertujuan untuk mengetahui (1) cara dan langkah-langlah guru menjaga kedekatan mereka dengan para siswa SMK Nadhlatun Nasyiin Kadur Pamekasan and (2) peran dari kedekatan guru-siswa dalam pembelajaran bahasa Inggris di SMK Nadhlatun Nasyiin Kadur Pamekasan. Penelitian ini adalah penelitian kualtatif dengan menggunakan pendekatan descriptive case study. Penelitian ini menjelaskan secara detail kedekatan guru-siswa di SMK Nadhlatun Nasyiin Kadur dalam pembelajaran bahasa Inggris termasuk cara-cara guru-siswa menjaga kedekatan meraka dan peran dari kedekatan mereka dalam pembelajaran bahasa Inggris Participants dalam penelitian ini adalah siswa kelas VII di SMK Nadhlatun Nasyiin Kadur. Observasi dan interview dilakukan untuk memperoleh data kedekatan guru-siswa. Hasil penelitian ini menunjukkan bahwa terdapat lima cara guru untuk menjaga kedekatan dengan siswa di SMK Nadhkatun Nasyiin Kadur Pamekasan yaitu memberikan sapaan kepada siswa dengan cara memanggil nama-nama siswa tiap kali masuk kelas, memberikan pertanyaan kepada siswa, memberikan tugas, memberikan siswa motivasi untuk berbicara bahasa Inggris, dan memberikan siswa kesempatan untuk berbicara bahasa Inggris. Peran dari kedekatan guru siswa dalam pembelajaran bahasa Inggris di SMK Nadhlatun Nasyiin Kadur Pamekasan adalah siswa dapat memiliki semangat atau termotivasi untuk belajar dan berbicara dengan menggunakan bahasa Inggris dan siswa memiliki tingkat kecemasan dan rasa takut yang rendah ketika belajar dan berbicara bahasa Inggris.
\end{abstract}

Kata Kunci: Kedekatan Guru-Siswa, Pembelajaran Bahasa Inggris 


\section{PENDAHULUAN}

Guru adalah orang yang dapat membangkitkan dan menciptakan aktifitas kelas yang kondusif, sehingga para siswa dapat melatih dan membiasakan diri menggunakan bahasa kedua. Guru mempunyai peran penting di dalam proses belajar mengajar. Mereka sebagai fasilitator, sumber, ahli, pemberi motivasi, pembimbing, dan model bagi siswa (TESOL International Association, 2013: 9). Mereka harus mampu melihat keinginan siswa dalam proses pembelajaran.

Segala aktivitas yang dilakukan guru adalah agar para siswa memiliki kecakapan berbahasa yang baik dan benar. Guru merasa senang apabila aktivitas yang dirancang dan direncanakan sesuai dengan keinginan dan terkait dengan informasi yang diperlukan siswa. Guru mempunyai peran penting menciptakan suasana kelas yang positif dan membantu proses belajar siswa.

Siswa yang memiliki tingkat percaya diri tinggi mempunyai kesempatan lebih banyak untuk mempraktekkan bahasa target. Kondisi kelas yang baik adalah kondisi kelas yang dapat memdorong siswa berbicara dengan bahasa target. Siswa tidak memiliki rasa takut untuk berbicara dengan bahasa target. Guru merupakan model bagi siswa, merekalah yang sering berinteraksi dengan siswa dalam proses pembelajaran, dengan demikian guru dapat mendorong para siswa untuk menggunakan bahasa target ketika berinteraksi baik dengan guru ataupun dengan sesame teman. Menciptakan kondisi kelas yang menekankan pada pengayaan bahasa target merupakan suatu keharusan yang dilakukan guru.

Bahasa Inggris merupakan salah satu bahasa target yang dipejari siswa disekolah. Penting bagi siswa untuk berbagi ide, pikiran, perasaan, dll. Pengenalan perasan dan pikiran orang lain (empaty) membantu guru mendorong siswa berbahasa Inggris (Krashen, 2009: 45). Empaty dapat mencipakan kondisi kelas yang positif. Empathic teachers adalah guru yang dapat memahami berfikir siswa dan menghargai pola pandang siswa. Empaty dapat memfasilitasi siswa berkomunikasi dengan bahasa Inggris, baik guru maupun siswa dapat saking member dan menerima informasi. Guru bertanggung jawab untuk mencipatakan suasana kelas yang dapat memotivasi siswa berbicara bahasa Inggris (Chen, 2008: 146).

Gass and Selingker (2008: 432) mengemukakan bahwa setiap guru memiliki karakteristik individu yang berbeda yang dapat mempengaruhi performa mereka di dalam kelas, dan juga dapat mempengaruhi capaian siswa. Karakteristik individu guru dapat membangkitkan gairah siswa berinteraksi dengan bahasa Inggris. Sebagian guru bersikap ramah, humoris, menjadi teman bagi siswa, sering membantu siswa, sering tersenyum, dll, namun sebagian yang lain tidak demikian. Karakteristik guru dalam proses pembelajaran menjadi salah satu kunci keberhasilan siswa dalam berbahasa Inggris.

Fenomena tersebut dialami oleh guru-siswa di SMK Nadhlatun Nasyiin Kadur. SMK Nadhlatun Nasyiin terletak di Kec. Kadur, Kabupaten Pamekasan. Siswa SMK NADHLATUN NASYIIN KADUR berasal dari berbagai daerah dan golongan. Sebagian dari mereka berasal dari daerah Kadur, dan sebagian yang lain berasala dari daerah diluar Kec. Kadur. Selain dari itu, mereka juga berasal dari Kab. Sumenep dan kabupaten lain di wilayah Jawa Timur. Hal ini menunjukkan bahwa SMK NADHLATUN NASYIIN KADUR dikenal banyak pihak dan memiliki kualitas yang bagus dalam administrasi, kurikulum, dan guru. Maka dari itu, penting untuk dikaji 
lebih lanjut tentang kedekatan guru-siswa dalam proses pembelajaran bahasa Inggris di SMK Nadhlatun Nasyiin Kadur Pamekasan yaitu (1) cara guru menjaga menjaga kedekatan atau memiliki hubungan yang baik dengan siswa dan (2) peran kedekatan tersebut dalam pembelajaran bahasa Inggris.

\section{METODE}

Penelitian ini adalah penelitian kualitatif dengan menggunakan pendekatan descriptive case study. Penelitian ini menjelaskan secara detail kedekatan gurusiswa di SMK NADHLATUN NASYIIN KADUR dalam pembelajaran bahasa Inggris termasuk cara-cara guru-siswa menjaga kedekatan meraka dan peran dari kedekatan mereka dalam pembelajaran bahasa Inggris

Participants dalam penelitian ini adalah siswa kelas VII di SMK NADHLATUN NASYIIN KADUR. Berdasarkan dari pra-penelitian ditemukan bahwa guru-siswa di SMK NADHLATUN
NASYIIN KADUR memiliki kedekatan sosial, ada tegur sapa antara guru dan murid dan juga senyuman biasa diberikan guru ketika bersua dengan siswa. Observasi, angket dan interview dilakukan untuk memperoleh data kedekatan guru-siswa. Setelah data diperoleh dilanjutkan dengan penyederhanaan data yang telah diperoleh, kemudian dilakukan identifikasi data dan pembuatan kesimpulan.

\section{TEMUAN DAN PEMBAHASAN}

\section{A. Temuan}

1. Cara Guru Menjaga Kedekatan dengan Siswa

Didasarkan dari hasil observasi di SMK Nadhlatun Nasyiin Kadur Pamekasan, ditemukan beberapa cara guru bahasa Inggris untuk menjaga kedekatan dengan siswa. Temuan cara guru menjaga kedekatan dengan siswa di Nadhlatun Nasyiin Kadur Pamekasan di jelaskan pada Tabel 1.

Tabel 1. Cara Guru Menjaga Kedekatan dengan Siswa di Nadhlatun Nasyiin Kadur Pamekasan

\begin{tabular}{clcc}
\hline No. & Cara Guru Menjaga Kedekatan dengan Siswa & Frequensi & Persentase \\
\hline $\mathbf{1}$ & $\begin{array}{l}\text { Memberikan sapaan kepada siswa dengan cara } \\
\text { memanggil nama-nama siswa tiap kali masuk }\end{array}$ & 5 & $36 \%$ \\
& kelas & 1 & \\
$\mathbf{2}$ & Memberikan pertanyaan kepada siswa & 2 & $14 \%$ \\
$\mathbf{3}$ & Memberikan tugas & 4 & $29 \%$ \\
$\mathbf{4}$ & Memotivasi siswa & 2 & $14 \%$ \\
$\mathbf{5}$ & Memberikan siswa kesempatan untuk berbicara & & \\
\hline
\end{tabular}

Berdasarkan Tabel 1, terdapat lima cara guru untuk menjaga kedekatan dengan siswa di SMK Nadhkatun Nasyiin Kadur Pamekasan yaitu memberikan sapaan kepada siswa dengan cara memanggil nama-nama siswa tiap kali masuk kelas, memberikan pertanyaan kepada siswa, memberikan tugas, memberikan siswa motivasi untuk berbicara bahasa Inggris, dan memberikan siswa kesempatan untuk berbicara bahasa Inggris.

Memberikan sapaan kepada siswa dengan cara memanggil nama-nama siswa tiap kali masuk kelas adalah cara yang paling sering dilakukan oleh guru di SMK Nadhlatun Nasyiin untuk menjaga 
kedekatan dengan siswa, memberikan siswa motivasi untuk berbicara bahasa Inggris adalah cara kedua yang sering dilakukan oleh guru , memberikan siswa kesempatan untuk berbicara bahasa Inggris dan memberikan tugas merupakan cara yang ketiga yang biasa dilakukan guru, dan memberikan pertanyaan kepada siswa merupakan cara yang tidak terlalu sering dilakukan oleh guru di SMK Nadhlatun Nasyiin Kadur Pamekasan.

\section{Peran Kedekatan Guru dan Siswa dalam Pembelajaran Bahasa Inggris}

Tabel 2. Memaparkan tentang peran dari kedekatan guru dan siswa dalam pembelajaran bahasa Inggris. Dilakukan interview semi-structure yaitu dengan mengajukan beberapa pertanyaan kepada guru dan siswa di SMK Nadhlatun Nasyiin Kadur Pamekasan untuk memperoleh data tentang peran dari kedekatan guru dan siswa dalam pembelajaran bahasa Inggris

Tabel 2. Peran Kedekatan Guru dan Siswa dalam Pembelajaran Bahasa Inggris

\begin{tabular}{clcc}
\hline No. & $\begin{array}{c}\text { Peran Kedekatan Guru dan Siswa dalam } \\
\text { Pembelajaran Bahasa Inggris }\end{array}$ & Frequensi & Persentase \\
\hline 1 & $\begin{array}{l}\text { Memiliki semangat/termotivasi untuk } \\
\text { belajar/berbicara bahasa Inggris }\end{array}$ & 6 & $50 \%$ \\
2 & $\begin{array}{l}\text { Rendahnya rasa kecemasan/takut dalam } \\
\text { berbicara bahasa Inggris }\end{array}$ & 6 & $50 \%$ \\
\hline
\end{tabular}

Tabel 2. menunjukkan bahwa peran

dari kedekatan guru siswa dalam pembelajaran bahasa Inggris di SMK Nadhlatun Nasyiin Kadur Pamekasan adalah siswa dapat memiliki semangat atau termotivasi untuk belajar dan berbicara dengan menggunakan bahasa Inggris dan siswa memiliki tingkat kecemasan dan rasa takut yang rendah ketika belajar dan berbicara bahasa Inggris.

Siswa (50\%) di SMK Nadhlatun Nasyiin Kadur Pamekasan memiliki semangat dan termotivasi belajar untuk belajar atau berbicara bahasa Inggris ketika mereka memiliki kedekatan dengan guru. Siswa (50\%) di SMK Nadhlatun Nasyiin Kadur Pamekasan juga tidak memiliki rasa cemas dan takut untuk berbicara, belajar, serta menghadiri kelas bahasa Inggris ketika mereka dekat dengan guru.

B. Pembahasan

1. Cara Guru Menjaga Kedekatan dengan Siswa

$\mathrm{R} \quad$ : Namanya siapa dek?

$\mathrm{P} \quad$ : Hairul Anas

R : Oke hairul anas ... kan kamu sekolah di SMK Nadlatun
Kadur Pamekasan memberikan sapaan kepada siswa dengan cara memanggil nama-nama siswa tiap kali masuk kelas, memberikan pertanyaan kepada siswa, memberikan tugas, memberikan siswa motivasi untuk berbicara bahasa Inggris, dan memberikan siswa kesempatan untuk berbicara bahasa Inggris di depan kelas. Tujuan hal tersebut adalah demi terciptanya kedekatan antara guru siswa di SMK Nadhkatun Nasyiin Kadur Pamekasan. Untuk menciptakan kedekatan antara guru dan siswa di SMK Nadhlatun Nasyiin Kadur Pamekasan, guru memberikan sapaan kepada siswanya dengan cara memanggil nama mereka satu persatu di setiap memasuki kelas. Hal ini merupakan langkah pertama yang dilakukan oleh guru di SMK Nadhlatun Nasyiin Kadur Pamekasan seperti yang ditunjukkan dalam kutipan berikut ini. 
Nasyiin, di SMK Nadlatun Nasyiin kan ada guru dan siswa, kan kamu sudah kelas XI, nah yang mau saya tanyakan bagaimana guru bahasa inggris ketika ngajar menjaga kedekatan dengan siswa?ketika kamu memperhatikan gurunya.

$\mathrm{P} \quad$ : Sering memanggil siswanya dan sering berkomunikasi dengan siswa. Ketika masuk kelas memanggil nama siswa satu persatu dan berinteraksi dengan siswa

Berdasarkan hasil observasi yaitu dengan melakukan pengamatan terhadap situasi dan proses pembelajaran di SMK Nadhlatun Nasyiin Kadur Pamekasan sekaligus memberikan beberapa bertanyaan kepada siswa, yaitu Hairul Anas, salah satu siswa di SMK Nadhlatun Nasyiin Kadur Pamekasan, guru melakukan beberapa aktivitas yang dapat membangun kedekatan dengan siswa. Berdasarkan keterangan yang diberikan oleh siswa, di setiap memasuki kelas pada setiap pertemuan, untuk menciptakan interaksi antara guru dan siswa. Guru di SMK Nadlatun Nasyiin Kadur Pamekasan memanggil nama siswa dan sering berkomunikasi dengan siswa. Guru memanggil nama siswa bertujuan untuk menciptakan kedekatan antara guru dan siswa di SMK Nadhalatun Nasyiin Kadur Pamekasan.

Keterengan yang sama juga disampaikan oleh Andailatul Uswah tentang cara guru menjaga kedekatan dengan memberikan sapaan kepada siswanya. Guru di SMK Nadhalatun Nasyiin Kadur Pamekasan sebelum melakukan kegiatan pembelajaran seperti menulis, mengerjakan tugas, dll., guru mengabsen siswa satu persatu. Hal ini dilakukan agar tercipta suasana yang releks dan guru dapat memotivasi siswa untuk belajar dan berbicara bahasa Inggris. Memanggil nama siswa sebagai pembuka untuk memulai aktivitas pembelajaran yang dapat membangun kedekatan guru dan siswa. Panggilan yang dilakukan guru dapat menggugah rasa memiliki siswa terhadap kelas dikarenakan siswa merasa mendapat perhatian dari guru. Selain itu, sapaan dengan memanggil nama siswa juga dapat menjadi tahap awal membangun interaksi dengan siswa. Berikut ini adalah kutipan dari hasil observasi yang dilakukan dengan memberikan beberapa pertanyaan kepada Andailatul Uswah.

$$
\begin{aligned}
& \mathrm{R} \quad \text { : Namanya siapa dek? } \\
& \mathrm{P} \text { : Andailatul Uswah } \\
& \mathrm{R} \quad \text { : Panggilannya siapa? } \\
& \mathrm{P} \quad \text { : Naila } \\
& \mathrm{R} \text { : Naila ya... nama yang bagus naila }
\end{aligned}
$$

Nasyiin juga didukung oleh pernyataan guru bahasa Inggris mereka, yaitu bapak Mohammad Naili. Bapak Mohammad Naili menyatakan bahwa untuk menjaga kedekatan dengan siswa, guru bahasa Inggris memberikan sapaan kepada siswa. Sapaaan tersebut bertujuan untuk menjalin interaksi dengan siswa. Di SMK Nadhlatun Nasyiin Kadur Pamekasan. Guru bahasa Inggris selain dia sebagai guru bagi siswanya, dia juga memposisikan sebagai teman bagi para siswa. Siswa memiliki kesempatan untuk selalu berinteraksi dan bertukar pendapat dengan guru bahasa Inggris. Guru bahasa Inggris SMK 
Nadhlatun Nasyiin membangun rasa empati dengan siswa

Cara guru yang kedua di SMK Nadhaltun Nasyiin Kadur Pamekasan menjaga kedekatan dengan siswa adalah dengan cara memberikan pertanyaan kepada siswa. Memberikan pertanyaan kepada siswa merupakan cara kedua guru untuk membangun kedekatan dengan siswa. Hal ini dijelaskan pada kutipan berikut.

$\mathrm{R} \quad$ : Namanya siapa dek?

$\mathrm{P}$ : Mohammad Salim

R : Oke Mohammad Salim,saya mau bertanya ketika guru bahasa inggris mengajar,bagaimana guru bahasa inggris menjaga kedekatan dengan kalian?

$\mathrm{P}$ : Dengan cara banyak bertanya Pak

$\mathrm{R}$ : Berarti gurunya membangun pertanyaan. Oke, terus apa lagi dek?

Ketika dilakukan observasi di SMK Nadhlatun Nasyiin Kadur Pamekasan, siswa, Mohammad Salim memberikan keterangan bahwa salah satu cara yang dilakukan oleh guru untuk menjaga kedekatan dengan siswa adalah dengan memberikan pertanyaan kepada siswa. Guru memberikan beberapa pertanyaan kepada siswa agar terjadi komunikasi dan interaksi antara guru dan siswa. Pertanyaan yang diberikan guru kepada siswa terkait dengan kesulitan yang mereka hadapi dalam pembelajaran, keadaan mereka, dll yang dapat menstimulus terjadinya interaksi guru dan siswa.

Cara ketiga yang dilakukan guru untuk menjaga kedekatan dengan siswa di SMK Nadhalatun Nasyiin Kadur Pamekasan adalah dengan memberikan tugas kepada siswa seperti yang dijelaskan dalam kutipan berikut.

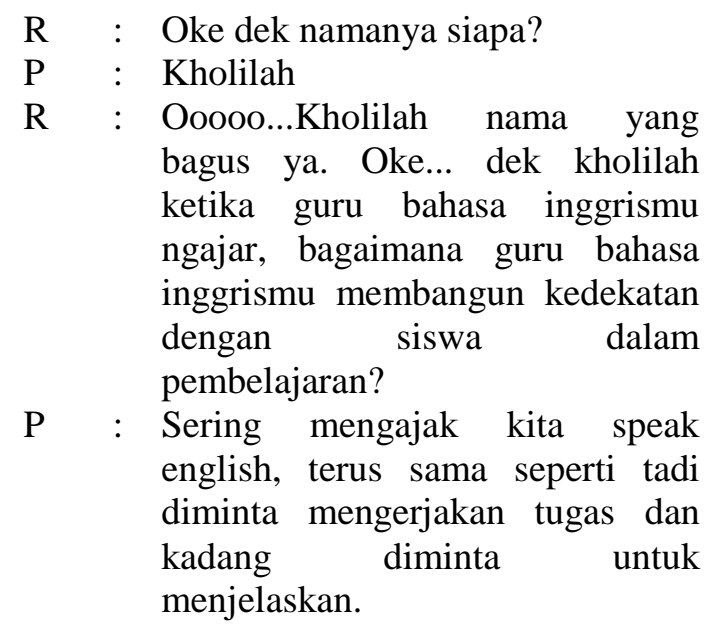

Pada waktu dilakukan observasi di SMK Nadhlatun Nasyiin Kadur Pamekasan, selain memanggil nama siswa dan memberikan pertanyaan kepada siswa, guru juga memberikan tugas kepada siswa. Pemberian tugas ini dilakukan agar guru memiliki kedekatan dengan siswa. Guru memberikan tugas kepada siswa dengan pendampingan dari guru. Guru memberikan tugas kepada siswa untuk membangun interaksi dengan guru dan interaksi dengan teman, sehingga dengan interaksi tersebut akan tercipta hubungan yang positif antara guru dan siswa. Pemberian tugas yang dilakukan guru di SMK Nadhalatun Nasyiin Kadur Pamekasan juga di ungkapkan oleh Andailatul Uswah pada kutipan berikut.

\begin{tabular}{|c|c|}
\hline & Namanya siapa dek? \\
\hline & Andailatul Uswah \\
\hline R & Panggilannya siapa? \\
\hline & Naila \\
\hline & $\begin{array}{l}\text { Naila ya... nama yang bagus naila } \\
\text { itu. Oke dek ketika guru bahasa } \\
\text { inggrismu mengajar, bagaimana } \\
\text { cara guru menjaga kedekatan } \\
\text { dengan siswa dalam pembelajaran } \\
\text { bahasa inggris? }\end{array}$ \\
\hline $\mathrm{P}$ & $\begin{array}{ll}\text { Diabsen dulu pak, terus nulis } \\
\text { setelah nulis } & \text { dijelaskan kalau } \\
\text { tidak ada yang mengerti } \\
\text { dijelaskan lagi } & \text { sampai beberapa }\end{array}$ \\
\hline
\end{tabular}




\author{
kali gitu pak \\ $\mathrm{R} \quad$ : Terus? \\ $\mathrm{P}$ : Guru memanggil nama siswa \\ satu-persatu dan memberikan \\ tugas agar terjadi interaksi antara \\ guru dan siswa. Supaya siswa \\ mau untuk bicara bahasa inggris \\ dan menulis bahasa inggris pak
}

Andailatul Uswah menyatakan bahwa untuk membangun dan menjaga kedekatan antara guru dan siswa di SMK Nadhlatun Nasyiin Kadur Pamekasan, guru memberikan tugas kepada siswa agar tercipta kondisi kelas yang kondusif dan rileks. Pemberian tugas yang bertujuan untuk menjalin komunikasi dengan siswa dapat menciptakan pembelajaran yang efektif dan memudahkan guru untuk member penjelasan tentang materi yang diajarkan.

Memberikan motivasi kepada siswa merupakan cara keempat yang dilakukan guru untuk menjaga kedekatan dengan siswa di SMK Nadhlatun Nasyiin Kadur Pamekasan. Guru bahasa Inggris selalu memberikan motivasi kepada siswa agar siswa di SMK Nadhlatun Nasyiin Kadur Pamekasan memiliki semangat dan gairah untuk belajar bahasa Inggris. Kutipan berikut ini memberikan penjelasan tentang motivasi guru kepada siswa di SMK Nadhlatun Nasyiin Kadur Pamekasan.

$\mathrm{R}$ : Kemudian apa lagi dek?

$P$ : Guru bahasa inggris sering memotivasi siswa untuk bicara bahasa inggris

$\mathrm{R}$ : Motivasi yang diberikan guru motivasi seperti apa dek?

$\mathrm{P}$ : Guru bilang bahasa inggris itu mudah pak

$\mathrm{R}$ : Terus gimana lagi dek cara gurunya untuk menjaga kedekatan itu?

P : Guru sering bilang kalau bahasa inggris lebih mudah dari bahasa arab dan bahasa madura terus bahasa indonesia, jadi anak-anak itu,gimana ya pak.... bilang gini "Oh masak bahasa inggris itu lebih mudah daripada bahasa arab dan lain-lain" kalau begitu saya harus semangat belajarbahasa inggris biar bisa

Pada saat dilakukan pengamatan tentang kedekatan guru-siswa dan cara guru menajaga kedekatan tersebut, kholilah, siswa di SMK Nadhlatun Nasyiin Kadur Pamekasan menginformasikan bahwa guru selalu memberikan motivasi kepada siswa untuk berbicara bahasa Inggris. Guru di SMK Nadhlatun Nasyiin Kadur Pamekasan menyatakan bahwa bahasa Inggris mudah untuk dipelajari dan berbicara dengan menggunakan bahasa Inggris mudah, bahasa Inggris lebih mudah dari bahasa Arab dan bahasa Indonesia. Infromasi ini dapat memotivasi siswa untuk belajar bahasa Inggris. Hal ini juga di pertegas oleh Andailatul Uswah. Memotivasi siswa untuk menghafal kosa kata bahasa Inggris dan menyuruh mereka serta memberikan semangat kepada mereka untuk berbicara bahasa Inggris merupakan cara yang dilakukan oleh guru di SMK Nadhalatun Nasyiin Kadur Pamekasan. Untuk menjalin dan mengikat hubungan emosional antara guru dan siswa, guru selalu memberikan arahan dan motivasi kepada siswa. Guru di SMK Nadhalatun Nasyiin Kadur Pamekasan juga memberikan wejangan kepada siswa tentang pentingnya menghafal kosa kata bahasa Inggris untuk menunjang percakapan menggunakan bahasa Inggris. Juga menganjurkan mereka untuk mempraktekkan bahasa Inggris mereka baik dengan guru ataupun dengan sesama siswa.

Guru di SMK Nadhlatun Nasyiin Kadur Pamekasan memberikan kesempatan kepada siswa untuk mengungkapkan pendapat, gagasan mereka dengan menggunakan bahasa Inggris adalah cara yang kelima yang dilakukan guru untuk 
menjaga kedekatan dengan siswa seperti dalam kutipan berikut ini.

$$
\begin{aligned}
\mathrm{R}: \text { : } & \text { Oke dek namanya siapa? } \\
\mathrm{P}: \text { Kholilah } & \\
\mathrm{R}: \text { : } & \text { Ooooo...Kholilah nama yang } \\
& \text { bagus ya. Oke... dek kholilah } \\
& \text { ketika guru bahasa inggrismu } \\
& \text { ngajar, bagaimana guru bahasa } \\
& \text { inggrismu membangun kedekatan } \\
& \text { dengan siswa dalam } \\
& \text { pembelajaran? } \\
\mathrm{P} \quad: & \text { Sering mengajak kita speak } \\
& \text { english, terus sama seperti tadi } \\
& \text { diminta mengerjakan tugas dan } \\
& \text { kadang diminta untuk } \\
& \text { menjelaskan. }
\end{aligned}
$$

Siswa di SMK Nadhlatun Nasyiin
Kadur Pamekasan mendapatkan
kesempatan untuk mempraktekkan bahasa
Inggris mereka dengan cara merespon
pertanyaan-pertanyaan yang diajukan guru
dan mengungkapkan pendapat mereka.
Selain itu, mereka berkonsultasi dan
bertukar pendapat dengan guru mereka
dengan menggunakan bahasa Inggris.
Untuk membangun kedekatan dengan
siswa, guru juga mengajak mereka
menggunakan dan melatih bahasa Inggris
mereka.

\section{Peran Kedekatan Guru dan Siswa dalam Pembelajaran Bahasa Inggris}

Peran dari kedekatan guru-siswa di SMK Nadhlatun Nasyiin Kadur Pamekasan adalah siswa memiliki semangat dan termotivasi untuk lebih giat belajar bahasa Inggris. Selain itu, kedekatan tersebut juga berdampak pada tingkat kecemahasan yang dimiliki siswa. Kedekatan tersebut membawa siswa pada rendahnya tingkat kecemasan dan rasa takut ketika berbicara dan belajar bahasa Inggris. Siswa memiliki semangat untuk belajar dan berbicara dengan menggunakan bahasa Inggris ketika mereka merasa dekat dengan guru mereka. Guru adalah model bagi mereka. Guru di
SMK Nadhlatun Nasyiin adalah pusat inspirasi bagi siswa. Aktivitas yang dilakukan guru dalam kelas dan sapaan guru membuat siswa memiliki semangat untuk belajar bahasa Inggris. Berikut ini adalah kutipan hasil wawancara dengan siswa terkait dengan semangat siswa ketika memiliki kedekatan dengan guru.

$$
\begin{aligned}
& \mathrm{R} \quad \text { : Namanya siapa dek? } \\
& \mathrm{P} \quad \text { : Hairul Anas } \\
& \mathrm{R} \text { : Terus dampak dari apa yang }
\end{aligned}
$$

$\begin{array}{rrr}\text { Guru } & \text { yang } & \text { memberikan } \\ \text { perhatiannya } & \text { kepada } & \text { siswa dapat }\end{array}$ menambah semangat dan motivasi siswa untuk belajar bahasa Inggris. Sapaan yang diberikan guru di SMK Nadhaltun Nasyiin Kadur Pamekasan mempengaruhi psikologis siswa. Siswa merasa diperhatikan oleh guru. Perhatian yang diberikan guru menunjukkan kalau mereka memiliki kedekatan. Perhatian tersebut yang membuat siswa memiliki rasa memiliki terhadap kelas. Siswa juga memiliki semangat untuk belajar bahasa Inggris. Khairus Anas, siswa di SMK Nadhlatun Nasyiin Kadur Pamekasan, memiliki semangat yang tinggi ketika guru memiliki kedekatan dengan siswa. Pernyataan serupa juga dikemukakan oleh Kholilah. Berikut ini adalah kutipan interview dengan Kholilah. 


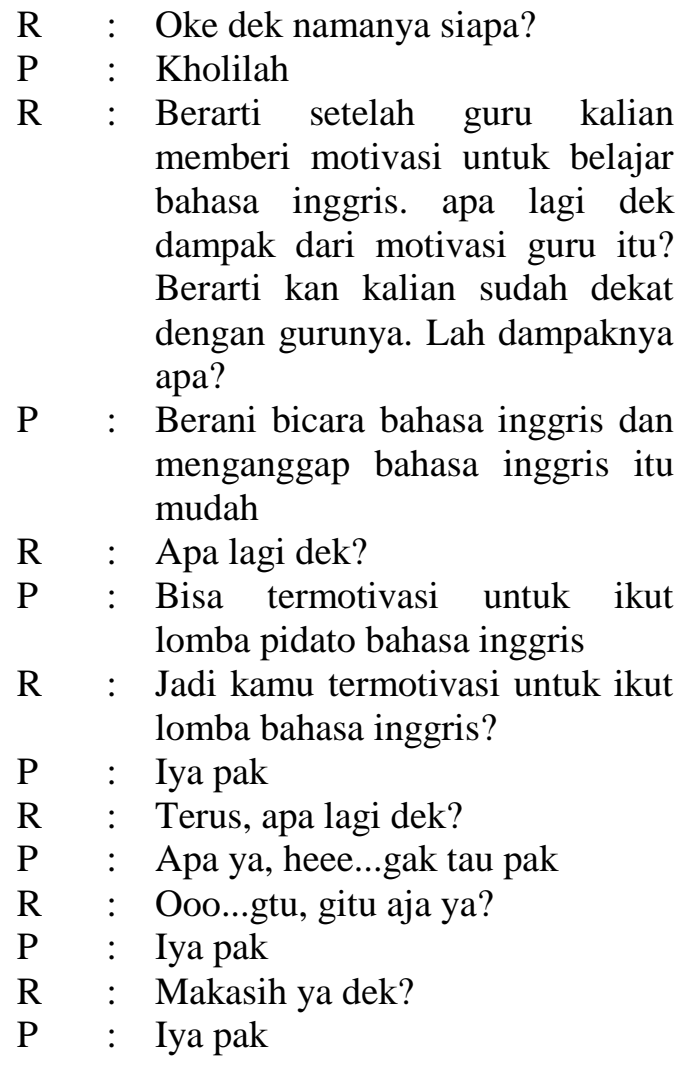

Siswa di SMK Nadhlatun Nasyiin Kadur Pamekasan termotivasi untuk belajar dan berbicara bahasa Inggris seperti ikut lomba pidato bahasa Inggris dan lomba lainnya ketika mereka memiliki kedekatan dengan guru. Kedekatan tersebut diwujudkan dalam pemberian semangat dan motivasi terhadap siswa. Hal ini merubah anggapan siswa yang awalnya menganggap bahasa Inggris adalah mata pelajaran yang sulit. Kedekatan guru dan siswa di SMK Nadhlatun Nasyiin Kadur Pamekasan menciptakan kondisi kelas yang positif yaitu siswa memiliki gairah untuk belajar dan menghadiri kelas bahasa Inggris karena dibenak mereka beranggapan bahwa bahasa Inggris mudah untuk dipelajari.

Kedekatan guru-siswa di SMK Nadhlatun Nasyiin Kadur Pamekasan berperan positif terhadap pembelajaran bahasa Inggris. Siswa yang awal mulanya tidak memiliki ketertarikan kepada bahasa Inggris, dengan kedekatan yang dimilki yaitu kedekatan antara guru dan siswa, mereka memiliki semangat untuk belajar bahasa Inggris. Selain itu, negative thinking terhadap bahasa Inggris berubah menjadi positif thingking kepada bahasa Inggris.

Peran dari kedekatan guru-siswa di SMK Nadhaltun Nasyiin kadur Pamekasan juga berdampak pada tingkat kecemasan yang dimiliki siswa. Siswa tidak memiliki rasa cemas dan takut untuk belajar bahasa Inggris. Siswa di SMK Nadhaltun Nasyiin kadur Pamekasan memiliki rasa takut dan cemas yang rendah terhadap kesalahan ketika belajar dan berbicara bahasa Inggris. Mereka mengungkapkan pendapat dan gagasan mereka dengan menggunakan bahasa Inggris tanpa adanya high anxiety level. Hal ini dikarenakan kedekatan yang mereka miliki dengan guru mereka. Berikut ini adalah kutipannya.

$$
\begin{aligned}
& \text { R : Namanya siapa dek? } \\
& \mathrm{P} \quad \text { : Mohammad Salim } \\
& \mathrm{R} \text { : Terus ketika kamu sudah dekat }
\end{aligned}
$$

Tingkat kecemasan atau rasa takut yang dimiliki siswa SMK Nadhlatun Nasyiin Kadur Pamekasan berkurang ketika mereka dekat dengan guru mereka. Mereka juga memiliki keberanian untuk berbicara bahasa Inggris serta menjawab soal bahasa Inggris. Kedekatan yang dimiliki dapat meminimalisir tingkat kecemasan serta 
tidak memiliki rasa takut untuk berbicara dengan bahasa Inggris.

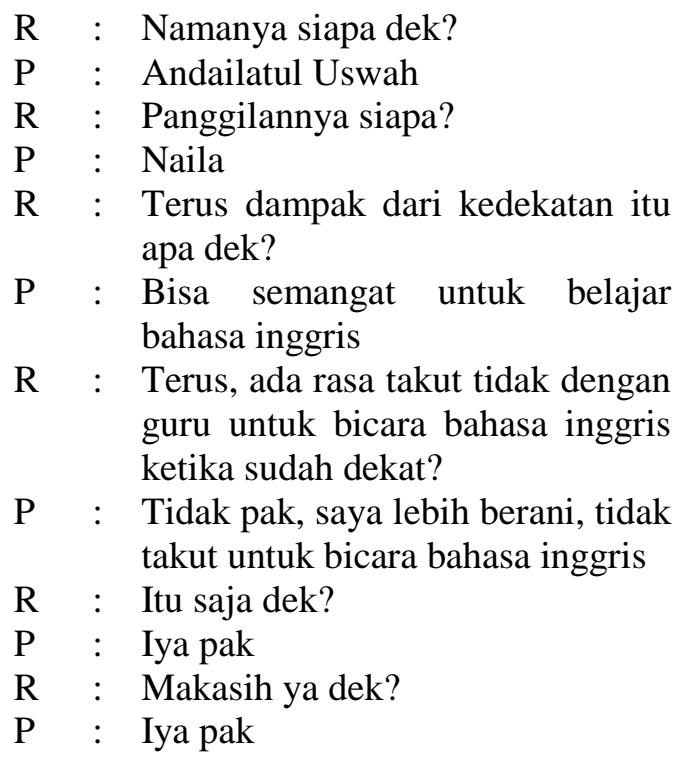

Andailatul Uswah yang biasa dipanggil dengan Naila juga menyatakan hal yang sama. Naila ketika ditanyakan tentang peran dari kedekatan guru-siswa terhadap pembelajaran bahasa Inggris, Naila menyatakan bahwa kedekatan antara guru dan siswa membuat dirinya lebih berani dan tidak takut untuk berbicara bahasa Inggris. Rasa nyaman terhadap kondisi kelas dalam pembelajaran bahasa Inggris juga di rasakan oleh siswa di SMK Nadhlatun Nasyiin Kadur ketika mereka dekat dengan guru mereka. Rasa nyaman tersebut membuat siswa memiliki keinginan untuk menguatarakan pendapat, bertukar fikiran dan berdiskusi denga guru dengan menggunakan bahasa Inggris.

Kedekatan guru dan siswa di SMK Nadhaltun Nasyiin tidak bermakna santai tanpa adanya kegiatan atau aktivitas pembelajaran, namun kegiatan pembelajaran bahasa berjalan sesuai dengan aturan-aturan yang ada. Kegiatan pembelajaran bahasa Inggris berlangsung dengan serius tetapi nyantai, tanpa adanya tekanan dari guru yang berdampak negatif seperti siswa memiliki rasa takut kepada guru dikarenakan guru sering melakukan hal-hal anarkis terhadap siswa, dll. Siswa mendapatkan rasa nyaman dan menikmati proses pembelajaran bahasa Inggris tanpa dibarengi dengan tingkat kecemasan yang tinggi dan rasa taku. Siswa di SMK Nadhaltun Nasyiin juga memiliki kesempatan dan keberanian untuk berkonsultasi dengan guru ketika mereka memiliki kedekatan. Siswa memiliki kesempatan untuk mempraktekkan bahasa Inggris yang telah mereka pelajari di depan kelas. Siswa juga memiliki kesempatan untuk share kepada guru terkait baik itu tentang akademik maupun non-akademik. Siswa juga mendiskusikan kesulitankesulitan yang dihadapi selama pembelajaran bahasa Inggris.

Kedekatan guru-siswa di SMK Nadhlatun Nasyiin dapat membantu siswa untuk berinteraksi menggunakan bahasa Inggris. Interaksi tersebut dapat memperkaya input siswa sehingga kedekatan tersebut dapat meningkatkan proficiency mereka. Kedekatan tersebut juga dapat memberikan rasa aman kepada siswa untuk berinteraksi dengan bahasa Inggris tanpa diselimuti rasa takut salah. Hal ini membantu siswa menjadi optimal user.

\section{KESIMPULAN}

Berdasarkan hasil temuan dan penjelasan dalam penelitian ini, beberapa kesimpuan dapat diformulasikan sebagai berikut (1) memberikan sapaan kepada siswa dengan cara memanggil nama-nama siswa tiap kali masuk kelas adalah cara yang paling sering dilakukan oleh guru di SMK Nadhlatun Nasyiin untuk menjaga kedekatan dengan siswa, memberikan siswa motivasi untuk berbicara bahasa Inggris adalah cara kedua yang sering dilakukan oleh guru , memberikan siswa kesempatan untuk berbicara bahasa Inggris dan memberikan tugas merupakan cara yang 
ketiga yang biasa dilakukan guru, dan memberikan pertanyaan kepada siswa merupakan cara yang tidak terlalu sering dilakukan oleh guru di SMK Nadhlatun Nasyiin Kadur Pamekasan dan (2) siswa di SMK Nadhlatun Nasyiin Kadur Pamekasan memiliki semangat dan termotivasi belajar untuk belajar atau berbicara bahasa Inggris ketika mereka memiliki kedekatan dengan guru. Selain itu, siswa di SMK Nadhlatun Nasyiin Kadur Pamekasan juga tidak memiliki rasa cemas dan takut untuk berbicara, belajar, serta menghadiri kelas bahasa Inggris ketika mereka dekat dengan guru.

\section{DAFTAR RUJUKAN}

Chen, L. (2008). The Effect of Empathy on College English Speaking. Asian Social Science, 4, 8.
Gass, S. M and Selingker, L. (2008). Second Language Acquisition. New York: Routledge

Krashen, S. D. (2009). Principle and Practice in Second Language Acquisition. california: University of Southern California.

Spratt, M., Pulverness, A, \& Williams, M. (2007). The Teaching Knowledge Test Course. New York: Cambridge University Press.

TESOL International Association. (2013). Implementing the Common Core State Standards for English Learner. 
48 JURNAL PENDIDIKAN EDUTAMA, Vo 5, No 2. Juli, 2018 